\title{
Influence of Afforestation on the Species Diversity of the Soil Seed Bank and Understory Vegetation in the Hill-Gullied Loess Plateau, China
}

\author{
Ning Wang ${ }^{1,2}$, Juying Jiao ${ }^{1, *}$, Yanfeng Jia ${ }^{3}$ and Dongli Wang ${ }^{4}$ \\ 1 State Key Laboratory of Soil Erosion and Dryland Farming on the Loess Plateau, \\ Institute of Soil and Water Conservation, CAS \& MWR, Yangling 712100, China; nwang123456@snnu.edu.cn \\ 2 School of Geography and Tourism, Shaanxi Normal University, Xi'an 710119, China \\ 3 College of Water Conservancy, Shenyang Agriculture University, Shenyang 110866, China; \\ yanfengjia@syau.edu.cn \\ 4 College of Environmental Science and Engineering, Liaoning Technical University, Fuxin 123000, China; \\ wangdongli@lntu.edu.cn \\ * Correspondence: jyjiao@ms.iswc.ac.cn; Tel.: +86-134-7437-5827; Fax: +86-29-8701-2210
}

Received: 25 September 2017; Accepted: 22 October 2017; Published: 24 October 2017

\begin{abstract}
The Chinese Loess Plateau region has long been suffering from serious soil erosion. Thus, large-scale afforestation has continued during the past decades in order to control soil erosion. Afforestation can dramatically alter nutrient cycles, affect soil-carbon storage, and change hydrology. However, it is unknown how afforestation influences species diversity of the soil seed bank and understory vegetation compared with spontaneous restoration of abandoned land. Forest land with trees planted 30 years ago, abandoned slope land restored spontaneously for 30 years, and the corresponding slopes with remnant natural vegetation were selected as sampling sites. The species richness both in the soil seed bank and vegetation was significantly higher on the afforested slope compared to the spontaneously restored abandoned land. The species similarity between the afforested slope and the remnant slope land was high both in the soil seed bank and standing vegetation compared to the abandoned land. The soil seed bank density varied from $1778 \pm 187$ to $3896 \pm 221$ seeds $/ \mathrm{m}^{2}$, and more than half of it was constituted by annual and biennial species, with no significant difference among sampling habitats. However, the afforested slope had higher seed density of grass and shrub/subshrubs compared to the abandoned slope. The present study indicates that in the study region, characterized by serious soil erosion, afforestation can better facilitate vegetation succession compared to spontaneously restoration of abandoned slope land.
\end{abstract}

Keywords: afforestation; soil erosion; species diversity; soil seed bank; abandoned land

\section{Introduction}

Soil erosion is regarded as one of the global environmental problems which cause land degradation and ecosystem disequilibrium [1]. In the Chinese hill-gullied Loess Plateau region, soil erosion is frequent and serious because of the special climate, complex landform and intensive human activity [2,3]. Previously, a large part of the natural vegetation had been destroyed and the land turned into farmland, thus aggravating soil erosion and ecological degradation [3]. It is estimated that nearly 1.6 billion tons of soil are lost from the plateau each year, and droughts, floods, and dust storms are common occurrences [4]. Therefore soil and water conservation is a vital problem that compromises the safety of both ecosystem and society. Revegetation is an effective approach to control soil erosion and improve the ecosystem. The presence of grass or trees can reduce runoff and conserve soil and water [5-7]. Thus, slope farmlands have been increasingly abandoned for revegetation [2,3]. 
However, the spontaneous revegetation process is slow because serious soil erosion causes loss of soil nutrient and water [8], as well as of plant diaspore [9-11]. Seedling survival and growth are further limited by abiotic factors, such as high temperature and radiation, limited availability of soil water [12], and physic damage caused by storms and slope runoff $[13,14]$. Under such conditions, native species regeneration may benefit from habitat amelioration by afforestation, which counteracts the above abiotic stress factors $[15,16]$. To this aim, some fast-growing and drought-resisting woody species, such as Robinia pseudoacacia and Caragana korshinskii, are planted to accelerate revegetation and ecosystem restoration.

Afforestation is considered an important approach to rehabilitate degraded lands and their ecosystems $[17,18]$. Generally, a forest is planted to control soil erosion, improve soil traits, provide habitat for species conservation, and offer other ecological services $[15,19,20]$. In the artificial forest or shrubland, microclimate and nutrient cycle are modified $[15,21,22]$ to influence the rate and trajectory of understory vegetation recovery and succession [23-25]. Herbaceous understory plays a key role in the restoration of biodiversity and in the conservation of soil and water in plantations. In temperate broadleaved forests, it forms the richest stratum in terms of plant diversity, and it influences the healthy development of the whole forest [26]. However, since afforestation influences the habitat and affects the understory plant recruitment and growth, intense debate surrounds the extent to which these anthropogenic forests protect or degrade biodiversity $[24,27,28]$. Tree species selections and site environments can also influence the subsequent species invasion and establishment, and later, the community structure and ecological function $[19,27,29,30]$.

The presence of a native seed source in the vicinity and its successful dispersal to the artificial forest are necessary for native seeds to contribute to the restoration of native biodiversity [31]. The seed dispersal and soil seed bank both play important roles in species recruitment and succession $[32,33]$. Studies indicate that tree plantations can facilitate native species regeneration by attracting seed dispersal agents from nearby native communities [34]. Simultaneously, the soil seed bank is an important component of vegetation dynamics [35]. In forests, soil seed banks bear the marks of former land use and forest management, and play an important role in vegetation dynamics [36]. The historical land use is a key factor that can influence the soil seed bank composition for a long-period [37-39]. Although the original vegetation is destroyed during land preparation and tree planting, many species persist in the soil as seeds [37,40]. In particular, pioneer species with a large soil seed bank would control the herbaceous layer at an early stage of afforestation or after disturbance [39]. However, during the development of the plantation, many of the open-field species which are shade-intolerable will disappear and will be replaced by successional species or native understory species [41].

The Loess Plateau region in northwest China is well-known of its serious soil erosion. Afforestation is broadly used to control soil erosion, accelerate vegetation restoration, and improve ecological environments $[18,42]$. The ecological impact of afforestation becomes the focus of intense debate during the afforestation process [42,43]. Being afforestation a primary measure of intervention, its influence on the soil characteristics such as soil erodibility, soil water, soil fertility [44,45], and its ecological function on erosion control, catchment-water yield and soil carbon sequestration were the focus of previous studies [46-48]. However, there is scarce knowledge about whether afforestation modifies the habitat to affect structure and species diversity of the soil seed bank and understory vegetation. The objectives of the present study were to assess the influence of afforestation on the soil seed bank and understory vegetation after 30 years of natural succession.

\section{Materials and Methods}

\subsection{Study Site}

This study was carried out in Zhifanggou watershed, which is located in An'sai county, in the Loess Plateau region $\left(109^{\circ} 19^{\prime} 30^{\prime \prime} \mathrm{E}, 36^{\circ} 51^{\prime} 30^{\prime \prime} \mathrm{N}\right)$ at $1010-1431 \mathrm{~m}$ above sea level. The watershed has 
a semiarid climate with an average annual precipitation of $505 \mathrm{~mm}(1970-2006)$. Over $60 \%$ of the precipitation falls during the rainy season (July-September), usually in the form of storms. The annual evaporation is over $1460 \mathrm{~mm}$, and the mean temperature is approximately $8.8^{\circ} \mathrm{C}$ (from $-11{ }^{\circ} \mathrm{C}$ to $30^{\circ} \mathrm{C}$ ). Within the study region, the landscape includes inter-gully slopes and gully slopes, and the land surface is fragmented by deeply incised and densely distributed gullies (gully density $8.06 \mathrm{~km} \cdot \mathrm{km}^{-2}$ ).

Although this area is located in the forest-steppe region, according to the literature the main body of the Loess Plateau appears to be covered by herbaceous or shrub species, but not by forest $[49,50]$. In fact, the native forest has almost been destroyed and replaced by typical steppe as a consequence of long-term human activity. Some native forest woody species are scattered over the steppe as isolated trees. The main native species in the different successional stages and landscapes are herbs, such as Artemisia scoparia, Artemisia gmelinii, Artemisia giraldii, Lespedeza davurica, Stipa bungeana, Bothriochloa ischaemun [44], and a few native shrubs, such as Rosa xanthina, Sophora viciifolia, and Syringa julianae. Broad planting species, such as R. pseudoacacia and C. korshinskii are also scattered throughout the landscapes.

\subsection{Soil Samples and Standing Vegetation Investigation}

In order to investigate the influence of afforestation on the soil seed bank, a south-facing slope planted with R. pseudoacacia and subject to natural succession for 30 years (Ps), and a north-facing slope planted with C. korshinskii and subject to natural succession for 30 years (Pn) were selected to collect soil samples. At the same time, south-facing and north-facing slope lands with remnant natural vegetation were selected ( $R s$ and $R n$, respectively). The soil samples prepared for germination experiments were collected in the four types of habitats. Nine plots, each $5 \mathrm{~m} \times 5 \mathrm{~m}$, were located on each habitat. At each plot, 20 soil cores (diameter $4.8 \mathrm{~cm}$ ) were collected in the $0-10 \mathrm{~cm}$ soil layers. The soil samples were collected in April, July and October in 2009. Additionally, the data about two abandoned slope lands (one a south-facing slope and the other a north-facing slope) with spontaneous restoration for 30 years (As and An, respectively) were used for comparison with the afforestation site. The soil seed bank samples in these two slopes were collected in April, August, and October in 2005. Every time, six $10 \mathrm{~cm} \times 10 \mathrm{~cm}$ soil samples of $0-10 \mathrm{~cm}$ in depth were collected separately from each slope. The understory vegetation and the standing vegetation on the remnant slope land and on the abandoned slope land were investigated in July of the study year. Three $1 \mathrm{~m} \times 1 \mathrm{~m}$ quadrats were surveyed in each sampling plot. The species composition was studied by recording the species that grew in the quadrat. The density of a given species was calculated as the number of individuals of that species per square meter. The coverage of each plant species was estimated by two experts at the same time.

\subsection{Germination Experiments}

The soil seed bank was identified using the germination method after the soil samples had been concentrated. The air-dried soil samples were sieved using a pore size of $0.15 \mathrm{~mm}$, and the soil retained in the sifter was the concentrated soil samples [51]. The germination experiment was conducted in a greenhouse. The concentrated soil samples were distributed over a $2 \mathrm{~cm}$ deep perlite layer in $24 \times 15 \times 5 \mathrm{~cm}$ plastic trays, to obtain a $0.5 \mathrm{~cm}$ high layer. During the experiments, the temperature in the greenhouse fluctuated between 11 and $35^{\circ} \mathrm{C}$, with a mean value of $25^{\circ} \mathrm{C}$. The germination trays were watered regularly. The seedlings were identified and removed, or replanted for later identification. The soil was dried and thoroughly stirred for the next germination period when no seedlings emerged within two weeks after the peak of seedling emergence. The germination experiment was terminated when there was no seedling emergence for four weeks, and the germination continued for approximately four months (15 March to 15 July in 2009). Also, the soil seed bank samples collected in 2005 were identified using the germination method [52]. 


\subsection{Statistical Analysis}

We characterized species richness, diversity and evenness in each habitat, in order to reveal the influence of afforestation on the soil seed bank and understory vegetation. Three species diversity indices were employed:

(1) Species number as the richness index $(S)$.

(2) Shannon-Wiener diversity index $\left(H^{\prime}\right)$ :

$$
H^{\prime}=-\sum\left(P_{i}\right) \ln \left(P_{i}\right),
$$

(3) Pielou evenness index $(J)$ :

$$
J=\frac{H^{\prime}}{\ln S^{\prime}}
$$

where $S$ is the number of species, $P_{i}$ is the proportion of individuals or the abundance of the $i$ th species expressed as a proportion of the total number of species in the community, and $\ln$ is the natural logarithm.

In order to reveal the differences in species composition between the soil seed bank and standing vegetation in the same and different habitats, Sorensen similarity coefficient was employed:

$$
C C=\frac{2 w}{a+b}
$$

where $C C$ is the Sorensen similarity coefficient; $w$ is the number of species present in both plots; $a$ and $b$ are the number of species in each of the investigated plot.

Species were ascribed to functional groups: annuals and biennials, perennial grasses, perennial herbs, semi-scrubs and shrubs, trees.

The differences in species diversity in both the soil seed bank and standing vegetation over different habitats were analyzed using ANOVA. The soil seed density was transformed using $\log (x+1)$ to satisfy the homogeneity of variance assumption.

\section{Results}

The soil seed bank density was significantly different among the habitats $(\mathrm{F}=3.988, p=0.007)$ (Figure 1). On the south-facing slope, the seed bank density was significantly lower on the abandoned land $\left(1778 \pm 187\right.$ seeds $\left./ \mathrm{m}^{2}\right)$ than on both the planted slope land $\left(3415 \pm 415\right.$ seeds $\left./ \mathrm{m}^{2}\right)$ and the land with remnant vegetation ( $3249 \pm 348$ seeds $\left./ \mathrm{m}^{2}\right)$, but there was no significant difference between the last two. On the north facing-slope, the seed bank density on the planted slope land $\left(2600 \pm 378\right.$ seeds $\left./ \mathrm{m}^{2}\right)$ was significantly lower than in the other two habitats. The soil seed bank species richness varied between $7.0 \pm 0.4$ and $23.4 \pm 1.2$, and was significantly different among the habitats $(\mathrm{F}=27.235$, $p<0.001)$. The species richness was significantly higher on the planted slope than on both the southand north-facing slopes of the abandoned land. However, the species richness was higher on the slope with remnant vegetation than on the planted slope, especially on the north-facing slope. 

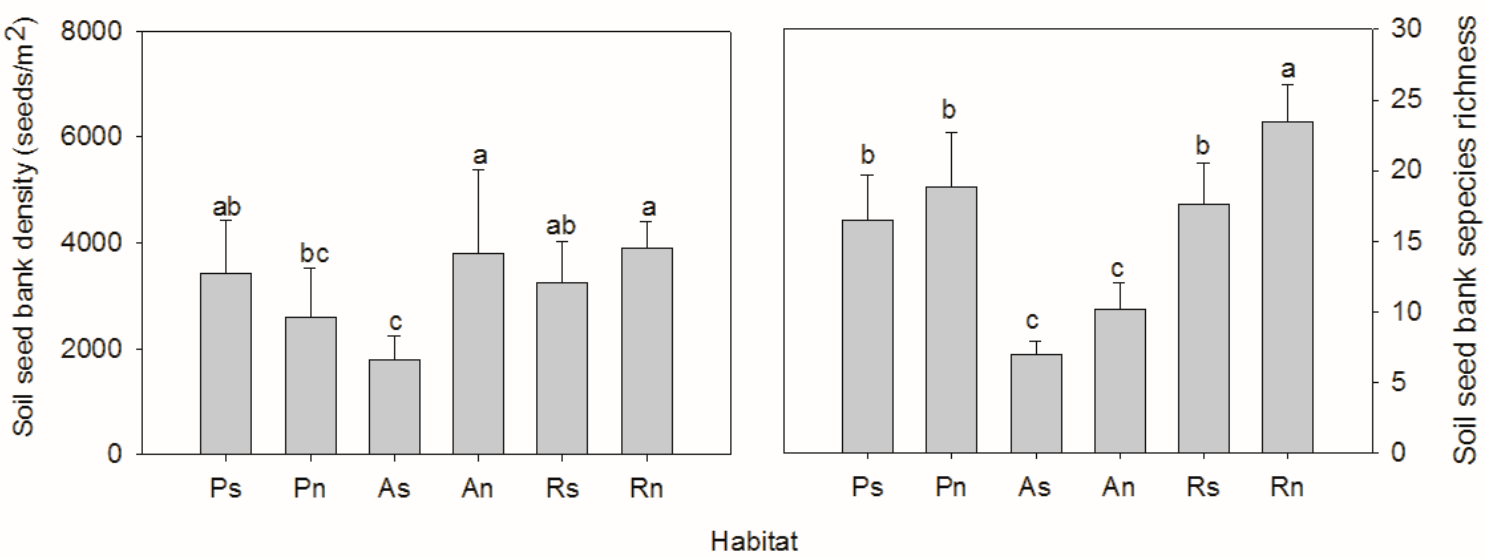

Figure 1. Soil seed bank density and species richness varied among different habitats (Ps/Pn—south/north-facing afforested slope land, As/An—south/north-facing abandoned slope land with spontaneous restoration, $\mathrm{Rs} / \mathrm{Rn}$-south/north-facing slope lands with remnant natural vegetation. The letters " $a, b, c$ " above the bar indicates significant difference at the 0.05 level).

The vegetation coverage varied significantly in the different habitats $(\mathrm{F}=10.488, p<0.001)$ (Figure 2). The understory vegetation on the south-facing planted slope had the lowest coverage $(15.8 \pm 0.9 \%)$, which was significantly lower than in the other two habitats. On the north-facing slope, the understory vegetation had the lowest coverage $(26.0 \pm 2.4 \%)$, which was close to the vegetation coverage on the remnant slope and significantly lower than the vegetation coverage on the abandoned slope. The species richness varied between $5.0 \pm 0.7$ and $11.2 \pm 1.6$, and was significantly different among habitats $(\mathrm{F}=9.660, p<0.001)$. The species richness on the abandoned slope was significantly lower than on the planted slope and the remnant slope, on both south- and north-facing aspects.
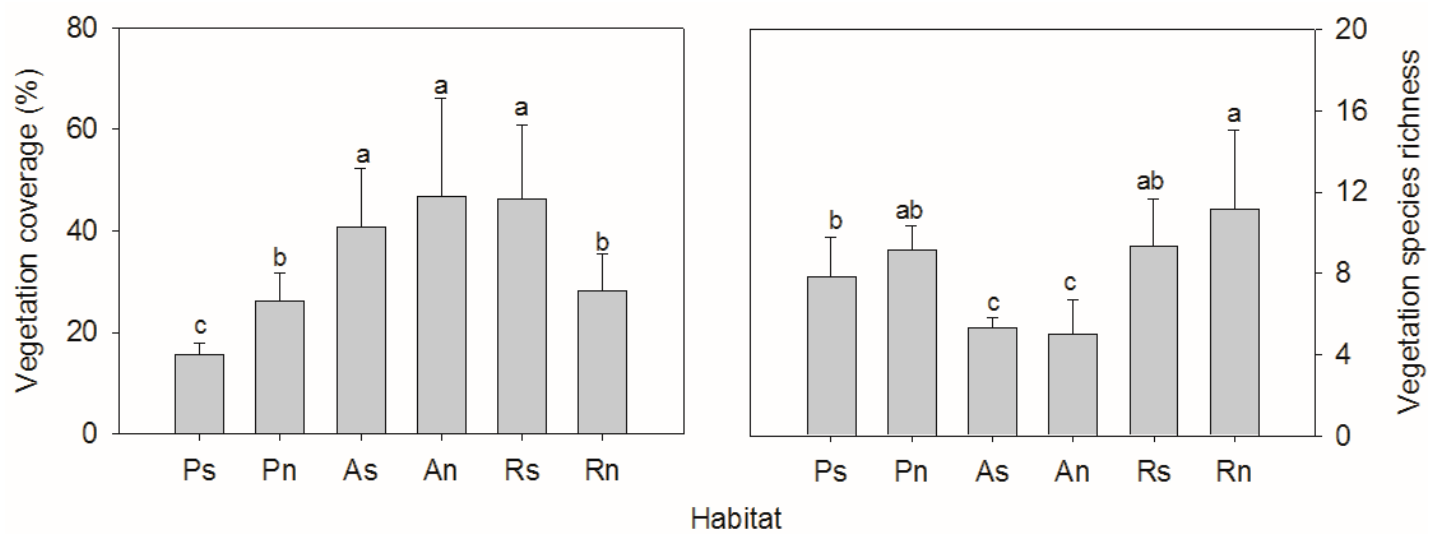

Figure 2. Vegetation coverage and species richness varied among different habitats (Ps/Pn—south/north-facing afforested slope land, As/An—south/north-facing abandoned slope land with spontaneous restoration, Rs/Rn-south/north-facing slope lands with remnant natural vegetation. The letters " $a, b, c$ " above the bar indicates significant difference at the 0.05 level).

In total, this study identified 88 species belonging to 35 families in the soil seed bank and in the standing vegetation (Table 1). In particular, 63 species belonging to 24 families and 50 species belonging to 20 families were identified in the soil seed bank and standing vegetation, respectively. The species belonging to composite, gramineae and leguminosae represented a large part of the identified species. The total number of species in the soil seed bank varied from 14 to 43 in different habitats. The slope remnant vegetation had the highest species number, whereas the abandoned slope land had the lowest 
species number. In the standing vegetation, the total species number varied from 12 to 27 , and the lowest species number was recorded on the abandoned land.

Table 1. The characteristics of soil seed bank and vegetation in different habitats.

\begin{tabular}{|c|c|c|c|c|c|c|c|c|c|c|c|c|}
\hline \multirow{2}{*}{ Species } & \multicolumn{6}{|c|}{ Soil Seed Bank (seeds/m²) } & \multicolumn{6}{|c|}{ Vegetation Cover (\%) } \\
\hline & Ps & Pn & As & An & Rs & Rn & Ps & Pn & As & An & Rs & Rn \\
\hline \multicolumn{13}{|l|}{ Annuals/biennials } \\
\hline Amaranthus tricolor & 2 & & & & & & & & & & & \\
\hline Androsace septentrionalis & & 23 & & 28 & 4 & & & & & & & \\
\hline Artemisia hedinii & 94 & 6 & & 250 & 553 & 11 & 0.2 & & & & & \\
\hline Artemisia scoparia & 1701 & 966 & 983 & 2072 & 1463 & 1448 & & 0.1 & & & & 0.1 \\
\hline Bidens pilosa & 3 & & & 6 & & & & & & & & \\
\hline Bothriospermum chinense & 5 & 31 & & & 4 & 4 & & & & & & \\
\hline Chenopodium serotinum & & & 11 & 11 & 4 & 2 & & & & & & \\
\hline Digitaria sanguinalis & & & & & 2 & & & & & & & \\
\hline Dracocephalum moldavica & 20 & 18 & 28 & 11 & 7 & 4 & 0.0 & & & 0.8 & & 0.1 \\
\hline Echinochloa crusgali & & & & & & 2 & & & & & & \\
\hline Euphorbia humifusa & 2 & 15 & 6 & 67 & 6 & 13 & & & & & & \\
\hline Eragrostis pilosa & 17 & 2 & & 6 & 15 & & & & & & & \\
\hline Galium aparine & & & & & & & 0.3 & & & & & \\
\hline Incarvillea sinensis & & & & & & & 0.1 & & & & & \\
\hline Ixeris polycephala & & 2 & & 11 & & 11 & & & & & & \\
\hline Kochia scoparia & 3 & & & & 2 & & & & & & & \\
\hline Leonurus artemisia & & & & & & 17 & & & & & & \\
\hline Linum stelleroides & & 12 & & & 15 & 26 & & & & & & \\
\hline Plantago asiatica & 2 & & & & 6 & 2 & & & & & & \\
\hline Salsola collina & 61 & 57 & & & 2 & & 0.6 & 0.9 & & & & \\
\hline Saussurea japonica & & & & & & & 0.1 & 0.1 & & 0.2 & & \\
\hline Setaria viridis & 78 & 21 & 22 & 122 & 35 & 83 & & & & 0.2 & & \\
\hline Sonchus oleraceus & & & & & 2 & & & & & & & \\
\hline Swertia bimaculata & 123 & 370 & & & & 133 & & & & & & \\
\hline Torilis scabra & & & & & 2 & & & & & & & \\
\hline Torularia humilis & & & 11 & & 158 & 50 & & & & & & \\
\hline \multicolumn{13}{|l|}{ Perennial herbs } \\
\hline Artemisia giraldii & & 12 & 6 & & 2 & 41 & & 0.6 & 0.8 & & 9.4 & 1.2 \\
\hline Artemisia mongolica & & & & & & & 0.3 & 0.4 & & & & 0.1 \\
\hline Astragalus adsurgens & & 3 & & 39 & 2 & 2 & & & & & & \\
\hline Astragalus scaberrimus & & & & & & & & & & & & 0.1 \\
\hline Bupleurum yinchowense & & 11 & & & & & & 0.4 & & & & \\
\hline Dendranthema indicum & & 3 & & & & 11 & & & & 1.7 & & 4.9 \\
\hline Diarthron linifolium & & & & & & & & 0.0 & & & & \\
\hline Geranium wilfordii & 3 & & & & & & & & & & & \\
\hline Gerbera anandria & & & & & & 7 & & & & & & \\
\hline Glycyrrhiza uralensis & & & & & & & 0.6 & 0.8 & 0.8 & & & 0.2 \\
\hline Heteropappus altaicus & 3 & 18 & 6 & 78 & 20 & 20 & 0.5 & 0.7 & 0.2 & & 0.1 & \\
\hline Ixeridium chinense & 57 & 11 & 11 & 11 & 55 & 13 & & & & & & \\
\hline Ixeris sonchifolia Bge. Hance & 149 & 48 & & 22 & 37 & 175 & 0.1 & & & & & 0.1 \\
\hline Leontopodium leontopodioides & & 2 & & & & & & & & & & 0.3 \\
\hline Linum perenne & 2 & & & & & & & & & & & \\
\hline Melilotus officinalis & 3 & 17 & & & 4 & 18 & & 0.1 & 1.7 & 0.7 & 0.1 & 0.3 \\
\hline Oxytropis discolor & & & & & & 2 & & & & & 0.1 & \\
\hline Patrinia scabiosaefolia & 12 & 23 & & 6 & 9 & 74 & & 2.1 & & 0.8 & & 3.6 \\
\hline Polygala tenuifolia & 17 & 2 & & & 11 & 2 & 0.1 & & & & 0.2 & \\
\hline Potentilla bifurca & & & & & & & & 0.7 & & & & 0.1 \\
\hline Potentilla tanacetifolia & & 66 & 44 & & 2 & 4 & & 0.2 & 0.8 & & & 0.0 \\
\hline Pulsatilla chinensis & & & & & & & & 0.2 & & & & \\
\hline Rubia cordifolia & & & & & & 2 & & & & & & \\
\hline Serratula centauroides & & & & & & & & & 0.2 & & & \\
\hline Thalictrum aquilegifolium & & & & & & & & & & 0.7 & & \\
\hline Vicia amoena Fisch. ex DC. & & 2 & & & & & & & & 0.3 & & 4.4 \\
\hline Viola dissecta & 2 & 29 & & & 9 & 15 & & 0.1 & & & & \\
\hline Viola philippica & & & & & & & 0.1 & & & & & \\
\hline
\end{tabular}


Table 1. Cont

\begin{tabular}{|c|c|c|c|c|c|c|c|c|c|c|c|c|}
\hline \multirow{2}{*}{ Species } & \multicolumn{6}{|c|}{ Soil Seed Bank (seeds/m²) } & \multicolumn{6}{|c|}{ Vegetation Cover (\%) } \\
\hline & Ps & Pn & As & An & Rs & $\mathbf{R n}$ & Ps & Pn & As & An & Rs & Rn \\
\hline \multicolumn{13}{|l|}{ Perennial grasses } \\
\hline $\begin{array}{l}\text { Bothriochloa ischcemum } \\
\text { Carex lanceolata }\end{array}$ & 3 & 11 & 556 & & 103 & $\begin{array}{c}4 \\
20\end{array}$ & 0.2 & & 29.0 & & 1.3 & \\
\hline Cleistogenes caespitosa & & & & & & & & & 0.2 & & & \\
\hline Cleistogenes chinensis & 6 & 8 & & & 311 & 17 & 0.3 & 0.4 & & & 3.6 & 0.1 \\
\hline Cleistogenes hancei & & & & & & 6 & & & & & & 0.3 \\
\hline Cleistogenes squarrosa & & & & 17 & & & & & 1.0 & 1.3 & & \\
\hline Helictotrichon schellianum & & & & & & & & 0.1 & & & & \\
\hline Koeleria cristata & & & & & & & & & & & & 0.5 \\
\hline Leymus secalinus & & & & & & 2 & & & & & & \\
\hline Melica radula & & & & & & 98 & & & & & & \\
\hline Melica scabrosa & 54 & 9 & & & & 24 & & 0.2 & & & & 0.4 \\
\hline Pennisetum centrasiaticum & & & & & & & & & & 0.2 & & \\
\hline Phragmites australis & & & & & & & 0.7 & 0.4 & & & & \\
\hline Poa sphondylodes & 63 & 193 & & 907 & 134 & 1074 & & & & & & 0.1 \\
\hline Stipa bungeana & 743 & 89 & 39 & 17 & 11 & 48 & 9.0 & 4.1 & 0.5 & 2.3 & 0.6 & 0.6 \\
\hline Roegneria kamoji & 2 & & & & & & 0.1 & & & & & 0.0 \\
\hline \multicolumn{13}{|l|}{ Shrubs/Sub-shrubs } \\
\hline Ampelopsis glandulosa & & & & & & & & & & 0.8 & & 1.7 \\
\hline Artemisia gmelinii & 52 & 180 & 11 & 89 & 41 & 326 & 1.3 & 11.8 & 2.2 & 30.0 & 7.7 & 8.5 \\
\hline Buddleja alternifolia & 3 & & & & 114 & 6 & & & & & 3.1 & \\
\hline Caragana korshinskii & & & & & & & & 1.2 & & 3.3 & & \\
\hline Clematis fruticosa & & & & & 4 & 2 & & & & & 0.9 & \\
\hline Lespedeza cuneata & & & & & & 2 & & & & & & 0.1 \\
\hline Lespedeza davurica & 5 & 9 & 44 & 33 & 77 & 13 & 0.7 & 0.8 & 3.3 & & 3.4 & 0.3 \\
\hline Lespedeza floribunda & & & & & & & & & & & 3.9 & \\
\hline Periploca sepium & & 2 & & & & & 0.5 & & & & 0.8 & 0.2 \\
\hline Prinsepia utilis & & & & & & & & & & & 2.3 & \\
\hline Sophora davidii & & & & & 24 & & & & & & 7.9 & \\
\hline Syringa oblata & & & & & & 6 & & & & & & \\
\hline Rubus parvifolius & & & & & & & & & & & & 0.1 \\
\hline Ziziphus jujuba & & & & & & & & & & & 0.3 & \\
\hline \multicolumn{13}{|l|}{ Trees } \\
\hline Ailanthus giraldii & & & & & & & & & & & 0.7 & \\
\hline Robinia pseudoacacia & 71 & 2 & & & & & & & & & & \\
\hline Ulmus pumila & & & & & & & & & & 3.3 & & \\
\hline
\end{tabular}

Note: Ps/Pn—south/ north-facing afforested slope land, As/An—south/north-facing abandoned slope land with spontaneous restoration, $\mathrm{Rs} / \mathrm{Rn}$-south/north-facing slope lands with remnant natural vegetation.

The species diversity indices of standing vegetation and the soil seed bank changed in the different habitats (Figure 3). The Shannon-Wiener diversity index for the soil seed bank $(\mathrm{F}=8.887, p<0.001)$ and standing vegetation $(\mathrm{F}=6.101, p<0.001)$ was significantly difference in the habitats. The abandoned slope had the lowest Shannon-Wiener diversity index compared to the planted slope and the remnant slope. However, the Pielou evenness index for the soil seed bank and standing vegetation was not significantly difference in different habitats. 

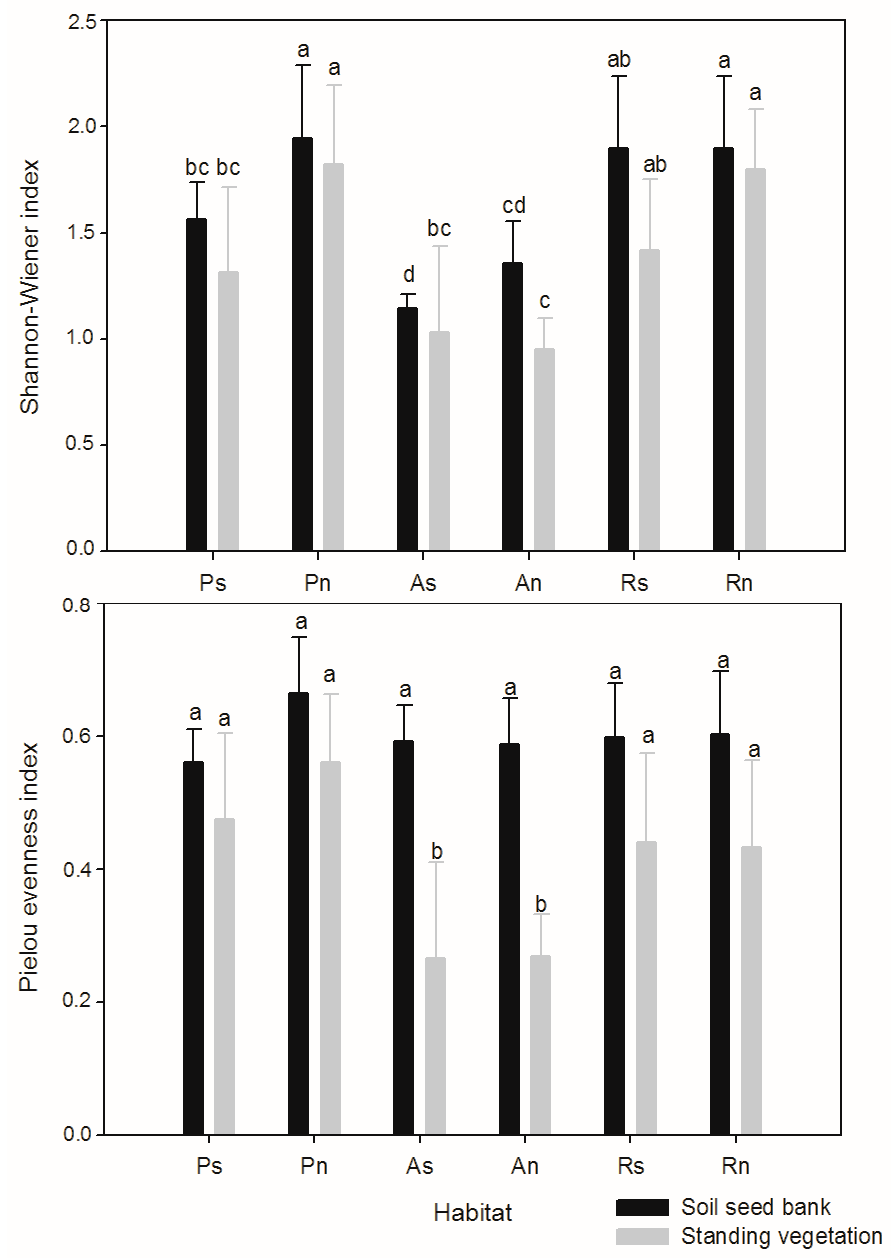

Figure 3. Species diversity of the soil seed bank and standing vegetation in different habitats (Ps/Pn—south/north-facing afforested slope land, As/An—south/north-facing abandoned slope land with spontaneous restoration, $\mathrm{Rs} / \mathrm{Rn}$-south/north-facing slope lands with remnant natural vegetation. The letters " $a, b, c$ " above the bar indicates significant difference at the 0.05 level).

The Sorensen similarity coefficient between standing vegetation and the soil seed bank changed from $0.19 \pm 0.05$ to $0.43 \pm 0.05$, and was significantly difference in the different habitats $(\mathrm{F}=6.087$, $p=0.001$ ) (Figure 4). On the south-facing slope, the similarity coefficient was the lowest on the planted slope, and the highest on the abandoned slope. On the north-facing slope, the similarity coefficient was the lowest on the abandoned slope, and whereas it had similar value in the other two habitats. Regarding the soil seed bank, the similarity coefficient between the planted slope and remnant slope was 0.69 and 0.70 , on both the south- and north-facing slopes (for the abandoned slope and remnant slope, it was 0.55 and 0.53 on both the south- and north-facing slopes). Regarding the standing vegetation, the similarity coefficient between the planted slope and remnant slope was 0.41 and 0.52 on both the south- and north-facing slope (for the abandoned slope and remnant slope, it was 0.47 and 0.38 on both the south- and north-facing slope). 


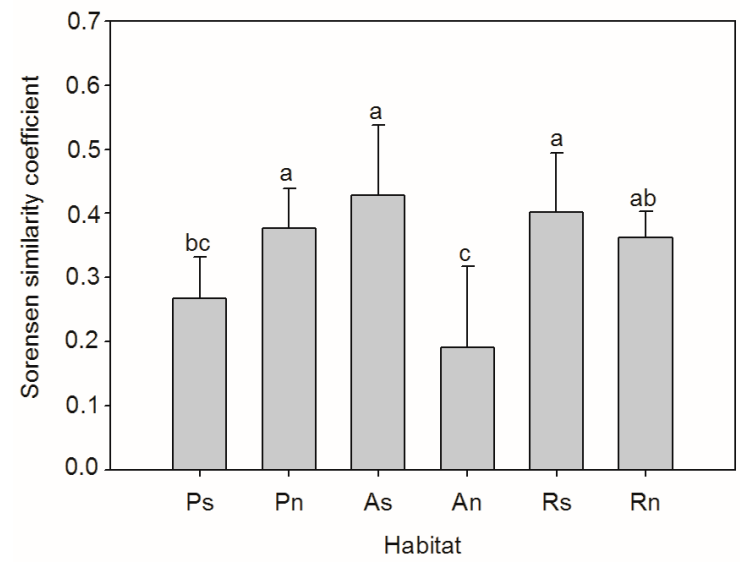

Figure 4. The Sorensen similarity coefficient between the soil seed bank and standing vegetation in different habitats (Ps/Pn—south/north-facing afforested slope land, As/An—south/north-facing abandoned slope land with spontaneous restoration, Rs/Rn—south/north-facing slope lands with remnant natural vegetation. The letters " $a, b, c$ " above the bar indicates significant difference at the 0.05 level).

The proportion of species belonging to different function groups in the soil seed bank and standing vegetation varied among the habitats (Table 2). In every habitat, the annuals/biennials species constituted more than half of the soil seed bank density (with the exception of the south-facing remnant slope), with the species number taking more than $30 \%$. However, in the vegetation, these species had low coverage, and even no coverage in the south-facing abandoned slope and remnant slope. The species richness of perennial herbs was more than $25 \%$ both in the soil seed bank and standing vegetation, but their soil seed bank density was low. A few species belonging to shrub and subshrub were found in the soil seed bank, but in the vegetation they had higher coverage, especially on the south-facing remnant slope and north-facing abandoned slope. In the sampling plots, the native tree species were rare both in the soil seed bank and standing vegetation.

Table 2. The soil seed bank density and vegetation coverage of different function groups vary among different habitats (A, Annuals/biennials, P, Perennial herbs, G, Perennial grasses, S, shrubs/sub-shrubs, T, Trees).

\begin{tabular}{cccccccc}
\hline Items & & Ps & Pn & As & An & Rs & Rn \\
\hline & A & 2109 & 1523 & 1061 & 2583 & 2277 & 1803 \\
Soil seed bank density (seeds $/ \mathrm{m}^{2}$ ) & P & 247 & 246 & 67 & 156 & 151 & 385 \\
& G & 870 & 310 & 594 & 941 & 560 & 1291 \\
& S & 60 & 190 & 56 & 122 & 260 & 354 \\
& T & 71 & 2 & & & & \\
\hline \multirow{5}{*}{ Soil seed bank species richness } & A & 13 & 12 & 6 & 10 & 17 & 14 \\
& P & 9 & 14 & 4 & 5 & 10 & 14 \\
& G & 6 & 5 & 2 & 3 & 4 & 9 \\
& S & 3 & 3 & 2 & 2 & 5 & 6 \\
& T & 1 & 1 & & & & \\
\hline \multirow{5}{*}{ Vegetation cover (\%) } & A & 1.2 & 1.1 & & 1.2 & & 0.2 \\
& P & 1.6 & 6.0 & 4.5 & 4.2 & 9.9 & 15.1 \\
& G & 10.3 & 5.3 & 30.7 & 3.8 & 5.5 & 2.1 \\
& S & 2.5 & 13.8 & 5.5 & 34.2 & 30.3 & 10.9 \\
& T & & & & 3.3 & 0.7 & \\
\hline \multirow{3}{*}{ Vegetation species richness } & A & 6 & 3 & & 3 & & 2 \\
& P & 6 & 12 & 6 & 5 & 5 & 12 \\
& G & 5 & 5 & 4 & 3 & 3 & 7 \\
& S & 3 & 3 & 2 & 3 & 9 & 6 \\
& T & & & & 1 & 1 &
\end{tabular}

Note: Ps/Pn—south/north-facing afforested slope land, As/An—south/north-facing abandoned slope land with spontaneous restoration, $\mathrm{Rs} / \mathrm{Rn}$-south/north-facing slope lands with remnant natural vegetation. 


\section{Discussion}

Significant differences in the densities and species diversity of seeds in the soil seed bank among study habitats were found in this study. The density of the soil seed bank in the plantation changed from $2600 \pm 378$ to $3415 \pm 415$ seeds $/ \mathrm{m}^{2}$ in the $0-10 \mathrm{~cm}$ soil layer. This value was relatively low compared with the correspondent one determined for the abandoned slope land that underwent natural recovery for about 15 years and had a soil seed bank density greater than 10,000 seeds $/ \mathrm{m}^{2}$ [52]. The seed bank density in the plantation was similar to the one for a plantation in the rocky mountain region of Beijing, which was also planted with R. pseudoacacia and other deciduous broadleaf tree or shrub species [53]. The species number of the soil seed bank ranged from 14 to 43 . After 30 years of succession, the abandoned slope land had a lower species richness compared to the planted slope, on both south- and north-facing slopes. In addition, the species richness was similar on the planted slope and on the remnant slope. Moreover, the species richness in the standing vegetation was considerably higher on the planted slope than on the abandoned slope, on both the south- and north-facing slopes.

The Shannon-Wiener diversity index and Pielou evenness index of the soil seed bank and standing vegetation were not significantly different for plantation and remnant slope, but they were both higher compared to the abandoned slope land with natural restoration. Species diversity is the main indicator of community changes in the restoration of abandoned land in the Loess Plateau [54]. Therefore, these results indicated that, with respect to the abandoned land with natural restoration, the planting treatment had a positive influence on the diversity of soil seed bank and standing vegetation.

Previous studies in this region also indicated that afforestation can improve soil nutrients, vegetation structure, and species diversity $[28,43,55,56]$; in addition, plantations could improve available soil nutrients more significantly than natural grasslands in the gully areas where soil erosion is more serious [56]. In the R. pseudoacacia plantation, soil nutrients and moisture at the superficial soil layer improved with plantation succession age [57]. The planted forest and shrub land can also improve microenvironment factors. They effectively reduce sun radiation, air temperature, and soil temperature fluctuation, and enhance air humidity. Thus, in the study region with abiotic stress for vegetation regeneration, the plantation has a potentially positive role in the restoration of native biodiversity. The benefits of afforestation on the understory microenvironments and its positive role in native species succession were also found in other studies in stressed environments $[15,58]$.

The relationship between the soil seed bank and standing vegetation changed with vegetation types, succession period, and management regime. In this study, seeds belonging to annuals and biennials represented a large part of the soil seed bank in each habitat. In contrast, in the vegetation, these species were always present in a small proportion (Table 2). This is similar to what was found in studies on the abandoned slope land in this region, which showed that the annuals and biennials can persisted in the soil seed bank with a high density [51]. Even after 30 years of succession the annuals and biennials in the standing vegetation are still more diffused in the plantation than in the remnant slope land. The seeds of grasses, perennial herbs, shrub and subshrubs had a relatively low density in the seed bank, but they were rich in species composition as a consequence of their short longevity in the seed bank. Because of their longevity and ability of vegetative regeneration, these species were the most represented in the standing vegetation [51].

In the soil seed bank, species similarity between plantation and remnant slope land was high on both the south- and north-facing slopes (similarity coefficients were 0.74 and 0.73 , respectively). The dominant species in different successional stages on the abandoned slope land were investigated both in south-facing and north-facing plantation. Among these were the pioneer species A. scoparia, and the later stage species S. bungeana, L. davurica, B. ischcemum, C. chinensis, A. giraldii, A. gmelinii, etc. [44]. At the same time, in standing vegetation, the species similarity between plantation and remnant slope land was also higher compared to the species similarity between plantation and abandoned slope land. Many of the native perennial herbs, grasses and shrubs existed in plantations. In the study region, because of the high gully density, landscape mosaics are formed by patches 
of remnant vegetation, abandoned farmland, and plantation. This landscape is important for seed transmission from adjacent remnant vegetation patches to the plantation, and maintains the potential for recovery of the transformed sites [59]. Furthermore, plantation can improve the plant growth habitat, and more native species can resettle in plantations, so that the species similarity between plantation and remnant slope land is higher.

The tree species were rare both in the soil seed bank and in the standing vegetation. Even for planted species, the soil seed bank density was low for R. pseudoacacia, and no seed of C. korshinskii was found in the seed bank. The low seed density of $R$. pseudoacacia may be due to predation in the canopy seed bank and post-dispersal. The seedling of R. pseudoacacia was also rare in the forest. C. korshinskii is a sandy shrub, and seeds of C. korshinskii germinate quickly after dispersal. However, on the Loess land, the seed can-not get into the soil, so nearly all the germinated seeds died because of drought. For these reasons, it was difficulty for these two planted species to regenerate from seeds in the study region. The native tree species in the study region, such as Pyrus betulifolia, Salix matsudana, Populus simonii, Platycladus orientalis, etc. spread sparsely in the background of steppe and shrub [49]. The present vegetation type and pollen records from various topographic units show that herbs were dominant in this region [60]. One previous study indicated that the development of forests on abandoned fields takes 40-50 years in the Loess area of China [54]. However, in the present study, after 30 years of succession, there is no indication that the native forest species will recolonize the region. The lack of available propagule is one critical factor that limits native forest species regeneration [31,58]. In addition, the climate and Loess soil also limit forest development in this region $[49,60,61]$.

\section{Conclusions}

The present study indicated that there is a positive influence of afforestation on the native species restoration, with respect to species diversity of the soil seed bank and standing vegetation. After 30 years of succession, the understory species composition was more similar to the one in the remnant slope than the one in abandoned land with natural restoration. Thus, in a stressed environment with serious erosion soil, afforestation with appropriate species can help the native species to resettle. However, there was rare native shrub resettling, and no tree species resettling in the plantation. More research is needed to determine whether this is caused by a lack of available propagule, or by the climate and deep Loess soil.

Acknowledgments: This study was supported by the National Science Foundation of China projects (41501290; 41371280). We acknowledged the assistance of State Key Laboratory of Soil Erosion and Dryland Farming on the Loess Plateau.

Author Contributions: Ning Wang and Juying Jiao conceived and designed the experiments; Ning Wang, Yanfeng Jia and Dongli Wang performed the experiments; Ning Wang and Juying Jiao analyzed the data; Yanfeng Jia and Dongli Wang contributed materials; Ning Wang wrote the paper.

Conflicts of Interest: The authors declare no conflict of interest.

\section{References}

1. Pimentel, D.; Kounang, N. Ecology of Soil Erosion in Ecosystems. Ecosystems 1998, 1, 416-426. [CrossRef]

2. Zhang, Q.J.; Fu, B.J.; Chen, L.D.; Zhao, W.W.; Yang, Q.K.; Liu, G.B.; Gulinck, H. Dynamics and driving factors of agricultural landscape in the semiarid hilly area of the Loess Plateau, China. Agric. Ecosyst. Environ. 2004, 103, 535-543. [CrossRef]

3. Zhao, G.; Mu, X.; Wen, Z.; Wang, F.; Gao, P. Soil erosion, conservation and eco-environment changes in the Loess Plateau of China. Land Degrad. Dev. 2013, 24, 499-510. [CrossRef]

4. Shi, H.; Shao, M.A. Soil and water loss from the Loess Plateau in China. J. Arid Environ. 2000, 45, 9-20. [CrossRef]

5. Cerdà, A. Parent material and vegetation affect soil erosion in eastern Spain. Soil Sci. Soc. Am. J. 1999, 63, 362-368. [CrossRef] 
6. Lieskovský, J.; Kenderessy, P. Modeling the effect of vegetation cover and different tillage practices on soil erosion in vineyards: A case study in Vrable (Slovakia) using watem/sedem. Land Degrad. Dev. 2014, 25, 288-296. [CrossRef]

7. Zhou, Z.C.; Shangguan, Z.P.; Zhao, D. Modeling vegetation coverage and soil erosion in the Loess Plateau Area of China. Ecol. Model. 2006, 198, 263-268. [CrossRef]

8. Zheng, F.; He, X.; Gao, X.; Zhang, C.; Tang, K. Effects of erosion patterns on nutrient loss following deforestation on the Loess Plateau of China. Agric. Ecosyst. Environ. 2005, 108, 85-97. [CrossRef]

9. Cerdà, A.; García-Fayos, P. The influence of seed size and shape on their removal by water erosion. Catena 2002, 48, 293-301. [CrossRef]

10. García-Fayos, P.; Bochet, E.; Cerdà, A. Seed removal susceptibility through soil erosion shapes vegetation composition. Plant Soil 2010, 334, 289-297. [CrossRef]

11. Jiao, J.; Zou, H.; Jia, Y.; Wang, N. Research progress on the effects of soil erosion on vegetation. Acta Ecol. Sin. 2009, 29, 85-91. [CrossRef]

12. García-Fayos, P.; García-Ventoso, B.; Cerdà, A. Limitations to plant establishment on eroded slopes in southeastern Spain. J. Veg. Sci. 2000, 11, 77-86. [CrossRef]

13. De Luís, M.; Raventós, J.; González-Hidalgo, J.C. Fire and torrential rainfall: Effects on seedling establishment in Mediterranean gorse shrublands. J. Int. Assoc. Wildland Fire 2005, 14, 413-422. [CrossRef]

14. Wang, N.; Jiao, J.Y.; Lei, D.; Chen, Y.; Wang, D.L. Effect of rainfall erosion: Seedling damage and establishment problems. Land Degrad. Dev. 2014, 25, 565-572. [CrossRef]

15. Becerra, P.I.; Montenegro, G. The widely invasive tree Pinus radiata facilitates regeneration of native woody species in a semi-arid ecosystem. Appl. Veg. Sci. 2013, 16, 173-183. [CrossRef]

16. Gomez-Aparicio, L.; Zamora, R.; Gomez, J.M.; Hodar, J.A.; Catr, J.; Baraza, E. Applying plant facilitation to forest restoration: A meta-analysis of the useof shrubs as nurse plants. Ecol. Appl. 2004, 14, 1128-1138. [CrossRef]

17. Ciccarese, L.; Mattsson, A.; Pettenella, D. Ecosystem services from forest restoration: Thinking ahead. New For. 2012, 43, 543-560. [CrossRef]

18. Li, W. Degradation and restoration of forest ecosystems in China. For. Ecol. Manag. 2004, 201, $33-41$.

19. Chirino, E.; Bonet, A.; Bellot, J.; Sanchez, J.R. Effects of 30-year-old Aleppo pine plantations on runoff, soil erosion, and plant diversity in a semi-arid landscape in south eastern Spain. Catena 2006, 65, 19-29. [CrossRef]

20. Rey, F.; Berger, F. Management of Austrian black pine on marly lands for sustainable protection against erosion (Southern Alps, france). New For. 2006, 31, 535-543. [CrossRef]

21. Breshears, D.D.; Nyhan, J.W.; Heil, C.E.; Wilcox, B.P. Effects of woody plants on microclimate in asemiarid woodland: Soil temperature and evaporation in canopy and intercanopy patches. Int. J. Plant Sci. 1998, 159, 1010-1017. [CrossRef]

22. Wu, J.P.; Liu, Z.F.; Sun, Y.X.; Zhou, L.X.; Lin, Y.B.; Fu, S.L. Introduced Eucalytus urophylla plantations change the composition of the soil microbial community in subtropical China. Land Degrad. Dev. 2013, 24, 400-406. [CrossRef]

23. Cusack, D.; Montagnini, F. The role of native species plantations in recovery of understory woody diversity in degraded pasturelands of Costa Rica. For. Ecol. Manag. 2004, 188, 1-15. [CrossRef]

24. Brockerhoff, E.G.; Jactel, H.; Parrotta, J.A.; Quine, C.P.; Sayer, J. Plantation forests and biodiversity: Oxymoron or opportunity? Biodivers. Conserv. 2008, 17, 925-951. [CrossRef]

25. Kou, M.; Jiao, J.; Yin, Q.; Wang, N.; Wang, Z.; Li, Y.; Yu, W.; Wei, Y.; Yan, F.; Cao, B. Successional trajectory over 10 years of vegetation restoration of abandoned slope croplands in the Hill-gully region of the Loess Plateau. Land Degrad. Dev. 2016, 27, 919-932. [CrossRef]

26. Gilliam, F.S. The ecological significance of the herbaceous layer in temperate forest ecosystems. Bioscience 2007, 57, 845-858. [CrossRef]

27. Bremer, L.L.; Farley, K.A. Does plantation forestry restore biodiversity or create green deserts? A synthesis of the effects of land-use transitions on plant species richness. Biodivers. Conserv. 2010, 19, 3893-3915. [CrossRef]

28. Chen, L.; He, Z.; Zhu, X.; Du, J.; Yang, J.; Li, J. Impacts of afforestation on plant diversity, soil properties, and soil organic carbon storage in a semi-arid grassland of northwestern China. Catena 2016, 147, 300-307. [CrossRef] 
29. Butler, R.; Montagnini, F.; Arroyo, P. Woody understory plant diversity in pure and mixed native tree plantations at La Selva Biological Station, Costa Rica. For. Ecol. Manag. 2008, 255, 2251-2263. [CrossRef]

30. Martín-García, J.; Jactel, H.; Oria-de-Rueda, J.A.; Diez, J.J. The Effects of Poplar Plantations on Vascular Plant Diversity in Riparian Landscapes. Forests 2016, 7, 50. [CrossRef]

31. Norton, D.; Forbes, A. Can exotic pine trees assist in restoration? Appl. Veg. Sci. 2013, 16, 169-170. [CrossRef]

32. Bakker, J.P.; Poschlod, P.; Strykstra, R.J.; Bekker, R.M.; Thompson, K. Seed banks and seed dispersal: Important topics in restoration ecology. Acta Bot. Neerl. 1996, 45, 461-490. [CrossRef]

33. Plue, J.; Dupouey, J.L.; Verheyen, K.; Hermy, M. Forest seed banks along an intensity gradient of ancient agriculture. Seed Sci. Res. 2009, 19, 103-114. [CrossRef]

34. Zamora, C.O.; Montagnini, F. Seed rain and seed dispersal agents in pure and mixed plantations of native trees and abandoned pastures at La Selva Biological Station, Costa Rica. Restor. Ecol. 2007, 15, 453-461. [CrossRef]

35. Thompson, K. Seeds and seed banks. New Physiol. 1987, 106, 23-34. [CrossRef]

36. Plue, J.; Gils, B.V.; Peppler-Lisbach, C.; Schrijver, A.D.; Verheyen, K.; Hermy, M. Seed-bank convergence under different tree species during forest development. Perspect. Plant Ecol. Evol. Syst. 2010, 2, 211-218. [CrossRef]

37. Bossuyt, B.; Hermy, M. Influence of land use history on seed banks in European temperate forest ecosystems: A review. Ecography 2001, 24, 225-238. [CrossRef]

38. Plue, J.; Verheyen, K.; Calster, H.V.; Marage, D.; Thompson, K.; Kalamees, R.; Jankowska-Blaszczuk, M.; Bossuyt, B.; Hermy, M. Seed banks of temperate deciduous forests during secondary succession. J. Veg. Sci. 2010, 21, 965-978. [CrossRef]

39. Van Calster, H.; Chevalier, R.; Wyngene, B.; Archaux, F.; Verheyen, K.; Hermy, M. Long-term seed bank dynamics in a temperate forest under conversion from coppice-with-standards to high forest management. Appl. Veg. Sci. 2008, 11, 251-260. [CrossRef]

40. Bossuyt, B.; Honnay, O. Can the seed bank be used for ecological restoration? An overview of seed bank characteristics in European communities. J. Veg. Sci. 2008, 19, 875-884. [CrossRef]

41. Kozlowski, T.T. Physiological ecology of natural regeneration of harvested and disturbed forest stands: Implications for forest management. For. Ecol. Manag. 2002, 158, 195-221. [CrossRef]

42. Cao, S.; Chen, L.; Shankman, D.; Wang, C.; Wang, X.; Zhang, H. Excessive reliance on afforestation in China's arid and semi-arid regions: Lessons in ecological restoration. Earth Sci. Rev. 2011, 104, 240-245. [CrossRef]

43. Jiao, J.; Zhang, Z.; Bai, W.; Jia, Y.; Wang, N. Assessing the ecological success of restoration by afforestation on the Chinese Loess Plateau. Restor. Ecol. 2012, 20, 240-249. [CrossRef]

44. Jiao, J.; Tzanopoulos, J.; Xofis, P.; Bai, W.; Ma, X.; Mitchley, J. Can the study of natural vegetation succession assist in the control of soil erosion on abandoned croplands on the Loess Plateau, China? Restor. Ecol. 2007, 15, 391-399. [CrossRef]

45. Tateno, R.; Tokuchi, N.; Yamanaka, N.; Du, S.; Otsuki, K.; Shimamura, T.; Xue, Z.; Wang, S.; Hou, Q. Comparison of litterfall production and leaf litter decomposition between an exotic blacklocustplantation and an indigenous oak forest near Yan'an on the Loess Plateau, China. For. Ecol. Manag. 2007, 241, 84-90. [CrossRef]

46. Qiu, L.; Zhang, X.; Cheng, J.; Yin, X. Effects of black locust (Robinia pseudoacacia) on soil properties in the loessial gully region of the Loess Plateau, China. Plant Soil 2010, 332, 207-217. [CrossRef]

47. Chang, R.; Fu, B.; Liu, G.; Liu, S. Soil carbonsequestration potential for "Grain for Green" project in Loess Plateau, China. Environ. Manag. 2011, 48, 1158-1172. [CrossRef] [PubMed]

48. Wang, Y.; Yu, P.; Feger, K.; Wei, X.; Sun, G.; Bonell, M.; Xiong, W.; Zhang, S.; Xu, L. Annual runoff and evapotranspiration of forestlands and non-forestlands in selected basins of the Loess Plateau of China. Ecohydrology 2011, 4, 277-287. [CrossRef]

49. He, X.; Tian, J.; Tang, K.; Sun, J.; Matthews, J.A. Bio-climatic imprints on a Holocene loess palaeosol from China. J. Asian Earth Sci. 2004, 22, 455-464.

50. Lü, H.; Liu, D.; Guo, Z. Natural vegetation of geological and historical periods in Loess Plateau. Chin. Sci. Bull. 2003, 48, 411-416. [CrossRef]

51. Wang, N.; Jiao, J.; JIa, Y.; Wang, D. Seed persistence in the soil on eroded slopes in the hilly-gullied Loess Plateau region, China. Seed Sci. Res. 2011, 21, 295-304. [CrossRef] 
52. Wang, N.; Jiao, J.; JIa, Y.; Bai, W.; Zhang, Z. Germinable soil seed banks and the restoration potential of abandoned cropland on the Chinese hilly-gullied Loess Plateau. Environ. Manag. 2010, 6, 367-377. [CrossRef] [PubMed]

53. Hu, Z.; Yang, Y.; Leng, P.S.; Dou, D.Q.; Zhang, B.; Hou, B.F. Characteristics of soil seed bank in plantation forest in the rocky mountain region of Beijing, China. J. For. Res. 2013, 24, 91-97. [CrossRef]

54. Zhang, J.; Dong, Y. Factors affecting species diversity of plant communities and the restoration process in the loess area of China. Ecol. Eng. 2010, 36, 345-350. [CrossRef]

55. Jia, G.; Liu, B.; Wang, G.; Zhang, B. The microbial biomass and activity in soil with shrub (Caragana korshinskii K.) plantation in the semi-arid loess plateau in China. Eur. J. Soil Biol. 2010, 46, 6-10. [CrossRef]

56. Xu, M.; Zhang, J.; Liu, G.; Yamanaka, N. Soil properties in natural grassland, Caragana korshinskii planted shrubland, and Robinia pseudoacacia planted forest in gullies on the hilly Loess Plateau, China. Catena 2014, 119, 116-124. [CrossRef]

57. Kou, M.; Garcia-Fayos, P.; Hu, S.; Jiao, J. The effect of Robinia pseudoacacia afforestation on soil and vegetation properties in the Loess Plateau (China): A chronosequence approach. For. Ecol. Manag. 2016, 375, 146-158. [CrossRef]

58. Zahawi, R.A.; Augspurger, C.K. Early plant succession in abandoned pastures in Ecuador. Biotropica 1999, 31, 540-552. [CrossRef]

59. Ruprecht, E. Successfully recovered grassland: A promising example from Romanian old-fields. Restor. Ecol. 2006, 14, 473-480. [CrossRef]

60. Jiang, W.; Yang, S.; Yang, X.; Gu, N. Negative impacts of afforestation and economic forestry on the Chinese Loess Plateau and proposed solutions. Quatern. Int. 2016, 399, 165-173. [CrossRef]

61. Shi, H.; Wen, Z.; Paull, D.; Jiao, F. Distribution of Natural and Planted Forests in the Yanhe River Catchment: Have We Planted Trees on the Right Sites? Forests 2016, 7, 258. [CrossRef]

(C) 2017 by the authors. Licensee MDPI, Basel, Switzerland. This article is an open access article distributed under the terms and conditions of the Creative Commons Attribution (CC BY) license (http:/ / creativecommons.org/licenses/by/4.0/). 